\title{
Measuring attitudes towards Social Europe: \\ A multidimensional approach
}

\author{
Sharon Baute ${ }^{1}$ \\ Bart Meuleman ${ }^{1}$ \\ Koen Abts $^{12}$ \\ Marc Swyngedouw ${ }^{1}$
}

\author{
${ }^{1}$ University of Leuven \\ Centre for Sociological Research (CeSO) \\ Institute for Social and Political Opinion Research \\ 2 Tilburg University \\ Tilburg School of Social and Behavioural Sciences
}

\section{Accepted for publication in Social Indicators Research}

Corresponding author:

Sharon Baute

University of Leuven

Institute for Social and Political Opinion Research

Parkstraat 45 box 3601

3000 Leuven

Belgium

sharon.baute@kuleuven.be 


\title{
Measuring attitudes towards Social Europe:
}

\section{A multidimensional approach}

\begin{abstract}
Although the notion of 'Social Europe' can refer to different principles and policy options, most research narrows down attitudes towards Social Europe to a unidimensional construct. In this study, we instead propose a multi-dimensional approach, and contribute to the literature in three ways. First, we elaborate the notion of 'Social Europe' conceptually, and distinguish between the decision-making level for social policy, European social citizenship, harmonization, member-state solidarity and interpersonal solidarity. Second, analysing the 2014 Belgian National Election Study by means of confirmatory factor analysis we evidence that citizens indeed have distinct attitudes towards the policy principles and instruments of Social Europe. Although these attitudinal dimensions are interrelated, they cannot be reduced to a single Social Europe factor, meaning that citizens differentiate in their attitudes between various aspects of Social Europe. In addition, our research indicates that member-state solidarity is the primary aspect of Social Europe in public opinion, whereas the feature that has received most scholarly attention in empirical research to date - the preferred decisionmaking level for social policy - cannot be considered as a key component of attitudes towards Social Europe. Third, we investigate whether citizens with different educational levels conceptualize Social Europe similarly using multigroup confirmatory factor analysis. Results indicate that the attitudinal factor structure of Social Europe is largely equivalent among lower and higher-educated citizens.
\end{abstract}

Keywords: Social Europe, European integration, social dimension, public opinion, attitudes 


\section{Introduction}

For a long time, European integration was understood as being a project of open economies and closed welfare states, in which economic growth resulting from market liberalization would preserve the autonomy of the nationally-bounded welfare states (Castles et al. 2010; Ferrera 2005; Giubboni 2014). The development of a social dimension was a 'road not taken' (Leibfried and Pierson 1995; Rhodes and Mény 1998; Scharpf 2002). However, the idea of separate tracks soon turned out to be impossible, as the economic and social arenas are intrinsically intertwined. As a result, the EU has started to engage more actively in European-level social policymaking that affects social welfare in the various member states (Gerrits 2015). Furthermore, calls for deepening the social dimension in the EU have been heard in the public debate (e.g. Allespach and Machnig 2013; Habermas 2013; Nida-Rümelin et al. 2013). Some authors perceive 'Social Europe' as an opportunity to strengthen public support for European integration (Fernandes and Maslauskaite 2013b; Grozelier et al. 2013; Vandenbroucke 2013). The further development of a Social Europe is believed to increase the legitimacy and accountability of the European Union, as it would raise the profile of the EU as a provider of social protection. However, Eurobarometer data shows that almost half of the European citizens believe that the European project has not been beneficial to them and that the EU threatens social standards and national welfare (EB 65, EB 81; European Commission 2007, 2014).

The issue of Social Europe is controversial given the strong historical link between the national state and welfare policies. Although the role of the EU and the scope of its competences in social policy are contested (Føllesdal, Giorgi, and Heuberger 2007), citizens' opinions about European social policy have received surprisingly little scholarly attention to date. In this contribution, we argue that the measurement of citizens' attitudes towards Social Europe is the Achilles' heel of existing research. Current studies lack a clear conceptualization of Social Europe, including its dimensionality. As a result, the measurement of attitudes towards Social 
Europe is unsatisfactory. Most existing studies measure these attitudes by focusing on a single dimension (Bechtel, Hainmueller, and Margalit 2014; Burgoon 2009; Gerhards and Lengfeld 2013; Lengfeld, Schmidt, and Häuberer 2015), usually on what citizens consider to be the most appropriate level for social policymaking (national versus European) (Mau 2005; Beaudonnet 2013). Other studies (Berg 2007; Gerhards, Lengfeld, and Häuberer 2014) aggregate items that refer to different, conceptually distinct dimensions, such as the principles, degree, scope and instruments of EU-level social policy. Scientific knowledge regarding attitudes towards Social Europe - as well as the dimensionality of these attitudes and their interrelations - is seriously constrained by this lack of clarity regarding conceptualization and measurement.

In this article, we attempt to remedy these shortcomings and to clarify the operationalization of citizens' attitudes towards Social Europe. Concretely, we address the following three research questions: (1) Which different dimensions of Social Europe can we distinguish conceptually based on the principles, scope and instruments of EU-level social policy? (2) How can the attitudes towards these aspects of European social policy be operationalized and measured among citizens, and do citizens distinguish effectively between these dimensions, or is it instead possible to reduce the dimensions to a single underlying construct? (3) Do citizens with different educational levels conceptualize Social Europe in a similar way or not?

We analyse data from the 2014 Belgian National Election Study, and apply second-order confirmatory factor analysis to gain insights into the structure of attitudes towards Social Europe. By addressing these questions, we contribute to the conceptual and empirical validity of measurement of citizens' attitudes towards Social Europe, and help to progress empirical research in this field. As European integration moves forwards, it is plausible that attitudes become more complex and multi-faceted (Beaudonnet and Di Mauro 2012; Boomgaarden et al. 2011; Cautrès 2012), and that citizens are not equally positive or negative with regard to every aspect of Social Europe. 


\section{Conceptualising the dimensions of Social Europe}

Although the concept of Social Europe is frequently used, different meanings of it can be found in literature. ${ }^{1}$ In general, 'Social Europe' refers to EU governance that establishes supranational social policies and that affects social rights and policies in the member states. Martinsen and Vollaard's (2014: 680) definition formalizes a two-level perspective on Social Europe:

(1) the protection and extension of social rights by means of positive integration and market correcting/restricting policies, and (2) the intervention in national social policies to enforce the market and promote free movement, free competition and nondiscrimination. Whereas the imperatives of market correction and non-discrimination may establish (European) social rights, market enforcing and non-discrimination tend to weaken the spatial boundaries of the welfare state and challenge the traditional allocation principles for social sharing.

This definition highlights the different aspects of Social Europe and describes EU social policy integration as resulting from market-making, market-correcting and non-discrimination initiatives. In addition, the definition focuses exclusively on EU policymaking, not on member states' social policies, which are included in other approaches (Ferrera 2014; Vandenbroucke 2014).

Different constitutive dimensions of Social Europe emerge from the aforementioned literature. First, Social Europe includes decision making at the European level on specific social policy measures. Second, the concept may also refer to the Europeanization of social rights, linked with the free movement of people and the workforce. Third, a wide range of European social policies are oriented towards the harmonization of member states' social policies through social regulation and mutual surveillance. Last, Sangiovanni (2013) argues that EU solidarity

\footnotetext{
${ }^{1}$ For a discussion of the notion of the 'European Social Union' see Vandenbroucke $(2013,2014)$, for the 'European Social Model' see Alber (2006) and Jepsen and Pascual (2005), and for 'European social integration' see Threlfall (2007).
} 
essentially needs to incorporate the principles of member-state solidarity as well as the principles of transnational solidarity defining obligations among EU citizens. As a result, we distinguish five dimensions of Social Europe: a supranational decision-making level for social policy, European social citizenship rights, harmonization of the social policy of member states, solidarity between member states and interpersonal solidarity between European citizens.

Table 1 summarizes these dimensions, their most important related policy instruments and the existing empirical studies on citizens' attitudes towards these particular principles or instruments. Although the overview is not exhaustive, these main policy options represent the contours of EU social policy. ${ }^{2}$ Below, we elaborate the dimensions in greater detail.

\subsection{Decision-making level for social policy}

Social Europe implies at least some competences of policy making at the EU level to create supranational social policy or to intervene in member states' policies. Social Europe therefore relates to the decision-making level for social policy, referring to the level at which social policy should be determined: local, regional, national or supranational. The question of which level for decision making is appropriate can be answered on different grounds (De Winter and Swyngedouw 1999). Legally, the division of power between the EU and its member states is guided by the principle of subsidiarity, which authorizes intervention by the EU when the objectives of an action cannot be satisfactorily achieved by the member states (European Parliament 2015). Current multilevel governance implies that certain policy issues are dealt with by different governments, very often through shared competences (Leibfried 2000; Leibfried and Pierson 1995). The question of whether welfare issues should be subject to EU decision making is controversial, because it always contains a territorial dimension. In

\footnotetext{
${ }^{2}$ We do not include the social dialogue or collective bargaining at the EU level in our conceptualization, despite the fact that these can also be considered aspects of Social Europe (e.g. Gold 1993).
} 
essence, European social integration refers to a process of boundary redrawing, transferring social and welfare competences to the European level (Bartolini 2005; Ferrera 2005). 
Table 1: A conceptual framework of the dimensions of Social Europe and an overview of empirical studies

\begin{tabular}{|c|c|c|c|}
\hline Policy principles & Description & Policy instruments & Empirical studies on attitudes \\
\hline \multicolumn{3}{|c|}{ Level for decision making regarding social policy } & $\begin{array}{l}\text { Ray } 2004 \\
\text { Mau } 2005 \\
\text { Berg } 2007 \\
\text { Eichenberg and Dalton } 2007 \\
\text { Beaudonnet 2012, } 2013\end{array}$ \\
\hline $\begin{array}{l}\text { European social } \\
\text { citizenship }\end{array}$ & $\begin{array}{l}\text { The granting of social rights to EU } \\
\text { citizens or a Europeanization of social } \\
\text { rights }\end{array}$ & $\begin{array}{ll} & \text { Provide EU citizens with access to } \\
\text { national social protection schemes } \\
\text { - Portability of social rights to other } \\
\text { member states }\end{array}$ & $\begin{array}{l}\text { Berg } 2007 \\
\text { Gerhards and Lengfeld } 2013 \\
\text { Gerhards and Lengfeld } 2015\end{array}$ \\
\hline Harmonization & $\begin{array}{l}\text { Harmonization of national social } \\
\text { policies and improvement of national } \\
\text { social standards }\end{array}$ & $\begin{array}{ll}- & \text { Social regulations } \\
- & \text { Mutual surveillance }\end{array}$ & Gerhards, Lengfeld and Häuberer 2014 \\
\hline Member-state solidarity & $\begin{array}{l}\text { Redistribution between member states } \\
\text { of the EU }\end{array}$ & $\begin{array}{ll}- & \text { Structural funds } \\
- & \text { Bailouts }\end{array}$ & $\begin{array}{l}\text { Beaudonnet } 2014 \\
\text { Bechtel, Hainmueller and Margalit } 2014 \\
\text { Lengfeld, Schmidt and Häuberer } 2015\end{array}$ \\
\hline Interpersonal solidarity & Redistribution between EU citizens & $\begin{array}{ll}\text { - } & \text { European unemployment insurance } \\
\text { scheme } \\
\text { - } & \text { European child benefit } \\
\text { - } & \text { European minimum income benefit }\end{array}$ & l \\
\hline
\end{tabular}




\subsection{European social citizenship}

Granting social rights to EU citizens is a cornerstone of Social Europe, as it is constitutive in the development of European social citizenship (Bruzelius, Chase, and Seeleib-Kaiser 2014; Faist 2001; Gerhards and Lengfeld 2015; Magnusson and Stråth 2004; Schall 2012). From the beginning of the European integration process, EU social policy has been aimed at securing the free movement of workers. The 1957 Treaty of Rome granted EU citizens access to other member states' social security schemes and introduced the transferability of alreadyearned social security rights between member states. In this sense, social benefits and services are no longer restricted to a member states' own citizens and can be taken up by people residing outside of the state's territory (Bruzelius et al. 2014: 2; Falkner 2010: 301; Leibfried 2015). As European social citizenship prohibits welfare discrimination towards nonnationals, it offers a new perspective on social rights. The granting of social rights by EU institutions redefines the boundaries between insiders and outsiders in social sharing systems, because the process of European integration introduces a distinct EU citizenship decoupling some rights from national territories (Ferrera 2005: 43). ${ }^{3}$

\subsection{Harmonization: Social regulations and the open method of co-ordination}

A wider range of European social policy measures has been put into practice through the harmonization of member states' social policies (Falkner 2009a; Threlfall 2003). The harmonization of national social policies and the convergence of social standards are mainly addressed through social regulations. Social regulation refers to the regulatory regime that constrains or reinforces member state law making (Majone 1993). The increasing use of qualified majority voting instead of unanimous voting has contributed to a growing body of EU legislation (Martinsen and Vollaard 2014). There are three main fields of EU social regulation

\footnotetext{
3 The Treaty of Maastricht (1992) formally introduced EU citizenship, setting out that any national of a member state is legally also a 'citizen of the Union'.
} 
with large amounts of binding and non-binding norms: health and safety at work, other working conditions and equality in the workplace and beyond (Falkner 2009b, 2010). In some member states, the EU social regulations had considerable legal consequences due to inadequate national legislation, while in others no major changes were required. Nevertheless, these directives reduce the autonomy of national welfare states in policy design.

Mutual surveillance among national policymakers, mostly practised through the open method of co-ordination (OMC), is a second instrument that facilitates social policy harmonization. In contrast to social regulations, the $\mathrm{OMC}$ does not take competences away from national governments, but has potentially converging effects on national social policies through mutual learning and peer pressure (Hodson and Maher 2001; Porte, Pochet, and Room 2001; Scharpf 2002; Trubek and Trubek 2005; Von Maydell et al. 2006). Originally developed in the field of EU employment policy, the OMC has been steadily extended to health, pension reform, equal opportunities and social inclusion (Büchs 2007; de la Porte and Pochet 2012; Pochet 2005; Von Maydell et al. 2006).

\subsection{Member-state solidarity}

In addition to regulation, Social Europe also involves redistribution. An important redistributive principle in the EU is member-state solidarity, based on financial transfers among member states (Allen 2010; Crum 2011; Dougan and Spaventa 2005; Gerrits 2015; Raspotnik, Jacob, and Ventura 2012; Sangiovanni 2013). In particular, the various structural funds focus on reducing regional disparities in income, employment, investment and growth (Anderson 1995; Falkner 2010; Geyer 2000; Leibfried and Pierson 1995), in order to strengthen economic and social cohesion (Mau and Verwiebe 2010). ${ }^{4}$ In 2014, the structural and investment funds accounted for around 39 per cent of the EU's total budget, implying strong territorial

\footnotetext{
4 The agricultural fund of the Common Agricultural Policy (CAP) is also sometimes perceived as an element of the EU's social dimension (Seeleib-Kaiser 2013).
} 
redistribution between EU member states (European Commission 2015). The issue of whether and to what extent solidarity between EU member states should exist (Seeleib-Kaiser 2013) became crucial during the European debt crisis, when bailout operations for some Eurozone member states came into practice (Bechtel et al. 2014; Fernandes and Maslauskaite 2013b; Fernandes and Rubio 2012; Lengfeld et al. 2015). In reality, these fiscal aids are credits to be paid back and are given on the condition that austerity measures are taken. Nevertheless, these measures overturned the 'no bailout clause' and are considered as instruments of international redistribution (Bechtel et al. 2014) or member-state solidarity (Beaudonnet 2014; Gerhards and Lengfeld 2015).

\subsection{Interpersonal solidarity}

European integration not only connects states, but also citizens. Interpersonal solidarity refers to the willingness of citizens to share risks, to redistribute resources and to support each other in order to bridge social divisions. In this sense, interpersonal or transnational solidarity concerns obligations among EU citizens (Crum 2011; Sangiovanni 2013). Although a European welfare state with direct transfers between EU citizens does not exist, the political viability of a European social security system based on interpersonal solidarity has been debated (Kleinman 2002). In this scenario, national solidarity would be supplemented or even replaced by transnational solidarity. Specific policy proposals based on this logic concern a European unemployment insurance scheme (Fattibene 2015; Fernandes and Maslauskaite 2013a), a European child benefit (Levy, Matsaganis, and Sutherland 2013), and a European minimum income benefit (European Economic and Social Committee 2013; Pena-Casas and Denis 2014). For Eurozone countries, these policies may function as automatic fiscal stabilizers to redistribute money to countries that are hit by asymmetric shocks (Andor 2016; Atkinson and Marlier 2010; Dullien 2012; Fattibene 2015; Fichtner 2014; Levy et al. 2013). Nevertheless, they imply new forms of solidarity reaching beyond the logic of a Transfer Union, as they have essentially an interpersonal nature with resources redistributed between 
individuals rather than regions or countries. At the same time, the actual proposals of transnational solidarity do not require the full harmonization - no 'one size fits all' - of social security systems across Europe.

\section{Public attitudes towards Social Europe}

Empirical research on attitudes towards Social Europe is still in its infancy and as previously stated, most studies predominantly focus only on a single dimension (see Table 1). A number of studies analyse citizens' preferred decision-making level for social policy, using opinions on whether the local authorities, the (sub)national government or the EU should be responsible for social welfare (Beaudonnet 2012, 2013; Berg 2007; Eichenberg and Dalton 2007; Mau 2005; Ray 2004).

Other studies focus on a specific policy principle or instrument. First, public attitudes towards a European social citizenship are studied by measuring citizens' support or opposition towards the granting of social rights to non-national EU citizens who live or work in another EU country (Berg 2007; Gerhards and Lengfeld 2013, 2015). Although opinion towards the granting of social rights to non-nationals is often studied in literature on welfare chauvinism (e.g. Mewes and Mau 2012; van der Waal et al. 2010), very few studies focus on the Europeanization of social rights in particular.

Second, attitudes towards the harmonization of national social policies have been investigated by measuring citizens' support for a uniform social welfare system and a uniform minimum wage across the EU (Gerhards, Lengfeld, and Häuberer 2014). However, the implications of these policy measures can involve both regulation and redistribution, making it hard to categorize this approach exclusively within the harmonization dimension. Furthermore, no empirical studies have been conducted on the attitudes towards the EU's practices of social regulations or mutual surveillance (social OMCs) among member states. 
Some recent studies (Beaudonnet 2014; Bechtel et al. 2014; Lengfeld, Schmidt, and Häuberer 2015) investigate public opinion concerning both the principle and practice of member-state solidarity in the light of the European debt crisis. These studies capture citizens' attitudes towards the idea of bailout payments for over-indebted EU countries, opinions on the conditions under which countries should receive financial support and citizens' motivations to support international financial transfers within the EU. Nevertheless, attitudes towards member-state solidarity outside the crisis context or attitudes towards the EU's structural funds have not been surveyed to date.

In sum, empirical studies either focus on only one facet of Social Europe, or too-readily aggregate conceptually distinct dimensions into a single index, whereas other dimensions mainly attitudes towards interpersonal solidarity at European level - remain unexplored. Nevertheless, the fact that the pattern of relevant explanatory variables differs considerably according to the particular dimension studied (see for example Berg 2007; Gerhards, Lengfeld, and Häuberer 2014; Gerhards and Lengfeld 2013) does suggest that attitudes towards Social Europe cannot be reduced to a single dimension. To answer the question of which distinct attitudes towards Social Europe can be distinguished, and how these attitudes are interrelated, is only possible by testing the multidimensionality of attitudes in a measurement approach.

\section{Data and Methods}

\subsection{Data}

We analyse attitudes towards Social Europe using data from the 2014 Belgian National Election Study (BNES) organized by the Institute for Social and Political Opinion Research at the University of Leuven (ISPO-KU Leuven) (Abts et al. 2015). This post-electoral survey was carried out among a register-based probability sample of Belgians entitled to vote in the 2014 elections. On completion of a computer-assisted personal interview (response rate 47 per cent), respondents were asked to fill out a 20-page drop-off questionnaire, containing a 
specific module on Social Europe. Applying the principles of Dillman's Tailored Design Method (Dillman, Smyth, and Christian 2014), we were able to convince 74 per cent of the respondents to fill out and send back the drop-off questionnaire $(\mathrm{N}=1403)$. The realized sample includes 49.2 per cent men and 40.4 per cent people with tertiary education, and the mean age is 51.7 years. The elderly and higher educated are somewhat overrepresented compared with the 26 per cent who did not return the drop-off (mean age 45.2; 28.7 per cent with tertiary education). However, given that in this study we analyse relationships between variables rather than levels of support, the impact of this overrepresentation can reasonably be assumed to be limited (Heggestad et al. 2015).

\subsection{Indicators}

The first dimension, the preferred level for decision making regarding social policy is measured by means of three items, each referring to a specific policy area: 'unemployment benefits', 'pensions' and 'health care'. Respondents were asked to indicate the level at which they prefer decisions to be taken, choosing from the following four response categories: (1) exclusively EU, (2) largely EU, (3) largely national and (4) exclusively national. Compared with the Eurobarometer, our operationalization includes more clearly defined policy areas, and offers more fine-grained answer options with four categories instead of two. To uncover how the decision-making level for social policy relates to preferences regarding other policy areas, we also include indicators for two additional policy areas in the analyses: economic policy (indicators: budget and government spending, taxes and economic policy) and security and foreign policy (indicators: organized crime, migration and asylum policy, defence and army).

Furthermore, the questionnaire contains multi-item measurements for the other four

dimensions of Social Europe outlined in Table 1. An overview of the exact question wording and the frequency distributions for each of the items are provided in Appendix 1 and 2. 
Opinions about European social citizenship are operationalized by four Likert five-point agreedisagree items concerning citizens' attitudes towards the access of EU citizens to social benefits and protection in Belgium. One item concerns equal social rights, two items relate to prioritizing nationals and one item refers to the conditionality of social protection.

Attitudes towards harmonization are measured by support for four types of social regulations: obligations imposed on employers to protect health and safety at work, maximum weekly working hours, minimum terms of paid leave and minimum terms of maternity leave. Responses were coded on a five-point scale ranging from 'a very bad thing' to 'a very good thing'. Due to its complexity, we decided not to survey attitudes towards mutual surveillance through the open method of co-ordination (i.e. a second aspect of harmonization).

Attitudes towards member-state solidarity are measured by three items on a five-point scale referring to solidarity between the richer and poorer countries of the EU. These items concern supporting member states in economic difficulties, the amount of tax money being redistributed, and the necessity for solidarity between EU member states. Due to reasons of complexity and specificity, we choose not to refer specifically to bailout payments or to structural funds, but instead to general views about solidarity between more and less prosperous member states.

Lastly, interpersonal solidarity is measured by means of two separate scales. On the one hand, the attitude towards the principle of interpersonal solidarity is measured directly by two items: support for EU measures to reduce income disparities and support for a system of solidarity among all EU citizens. On the other hand, four other items tap into interpersonal solidarity indirectly by measuring support for the implementation of a European social security system. One item concerns the realization of an overall European welfare state, whereas the other three items refer to shared European protection schemes for specific policy areas: child allowances, minimum income benefits and unemployment benefits. 


\subsection{Statistical modelling}

Confirmatory factor analysis (CFA) is used to study the dimensionality of attitudes towards Social Europe. Testing competing models, the analysis proceeds in three stages. First, the issue of multidimensionality is addressed by specifying a model containing six dimensions, while also testing whether a second-order factor - support for Social Europe - can explain the interrelations between these dimensions. Second, we assess the validity of 'preferred decision-making level' as an indicator of attitudes towards Social Europe. Third, the issue of measurement invariance (Davidov et al. 2014) across the low and high educated is addressed by multigroup confirmatory factor analysis (MGCFA). All models are estimated using Mplus 7.3. The presence of missing data is dealt with by using full information maximum likelihood estimation (FIML) (Schafer and Graham, 2002). ${ }^{5}$

\section{Results}

\subsection{Attitudes towards Social Europe: Unidimensional or multidimensional?}

To investigate whether the postulated multidimensional structure is reflected in citizens' attitudes, we compare CFA models with competing attitude structures. Model 1 represents a CFA model in which the 20 selected items of Social Europe load on one factor. Global model fit indices (see Table 2) show very clearly that this unidimensional model does not fit the data adequately. Model 2 represents a CFA with six latent constructs (each measured by two ${ }^{6}$ to four indicators) that are uncorrelated. Fit indices improve substantially by specifying multiple

\footnotetext{
5 The ML estimation procedure assumes that the indicators are continuous and follow a multivariate normal distribution. Given that most of our indicators are five-point Likert items, this assumption is not fulfilled. However, simulation studies show that the ML estimator is robust against a violation of the normality assumption as long as there are at least five answer categories and the data is not overly skewed (DiStefano 2002; Muthén and Kaplan 1985; West, Finch, and Curran 1995). As a robustness check, we re-estimated the first and second-order factor models (Models 1-5) using robust weighted least squares (WLSMV) estimation for categorical data. This yielded very similar results, although factor loadings were slightly stronger and model fit was, depending on the fit index considered, marginally worse ( $\mathrm{X}^{2}, \mathrm{RMSEA}$ ) or somewhat better (CFI, TLI). In this article, we report the ML estimates because this procedure is more straightforward for testing measurement equivalence. The WLSMV results are available on request from the first author.

${ }^{6}$ In the uncorrelated model, factor loadings for the two indicators of 'interpersonal solidarity' - Q121_3 and Q121_7 - were set equal (constrained to 1) for reasons of model identification.
} 
dimensions instead of a single factor, but the overall fit of Model 2 remains unacceptable. Modification indices suggest an error correlation between two social regulation items, namely between support for the EU's social regulations on paid leave for employees and support for maternity leave. The inclusion of the error correlation improves the model fit significantly $\left(\Delta X^{2}=43.601\right.$ for 1 degree of freedom) and is theoretically justified because both items refer to similar instruments: regulations concerning leave. Based on these arguments, we include this error correlation in Model 2 and all subsequent models. In Model 3, the assumption that the dimensions are unrelated is relaxed, and correlations between the six latent constructs are included. Judging by all fit indices, Model 3 performs substantially better than the one without correlations (Model 2) and yields a satisfactory model fit. This confirms that the postulated dimensions of Social Europe constitute separate but interrelated dimensions.

Table 2: Fit indices of CFA models, attitudes towards Social Europe $(\mathrm{N}=1403)$

\begin{tabular}{|l|l|l|l|l|l|l|l|}
\hline Model & Description & $\mathrm{X}^{2}$ & $\mathrm{df}$ & $\mathrm{RMSEA}$ & $\mathrm{SRMR}$ & $\mathrm{CFI}$ & $\mathrm{TLI}$ \\
\hline 1 & Single-factor model & 4698.500 & 170 & 0.138 & 0.118 & 0.506 & 0.448 \\
\hline 2 & $\begin{array}{l}\text { First-order model with six uncorrelated } \\
\text { factors }\end{array}$ & 1514.033 & 170 & 0.075 & 0.149 & 0.853 & 0.836 \\
\hline 3 & First-order model with six correlated factors & 407.289 & 154 & 0.034 & 0.035 & 0.972 & 0.966 \\
\hline 4 & Second-order CFA (Social Europe) & 511.951 & 163 & 0.039 & 0.045 & 0.962 & 0.956 \\
\hline
\end{tabular}

In the fourth step, we investigate whether the pattern of correlations between the different dimensions of Social Europe can be accounted for by means of a single, underlying secondorder factor (Model 4). The second-order factor model has a good model fit, as the RMSEA equals 0.039 , the SRMR equals 0.045 and both the CFI (0.962) and TLI (0.956) are sufficiently close to 1 . This implies that the various attitudinal dimensions of Social Europe are, at least to some extent, expressions of a more general evaluation continuum. 
Figure 1: Second-order factor model with standardized factor loadings (Model 4; $\mathrm{N}=1403$ ).

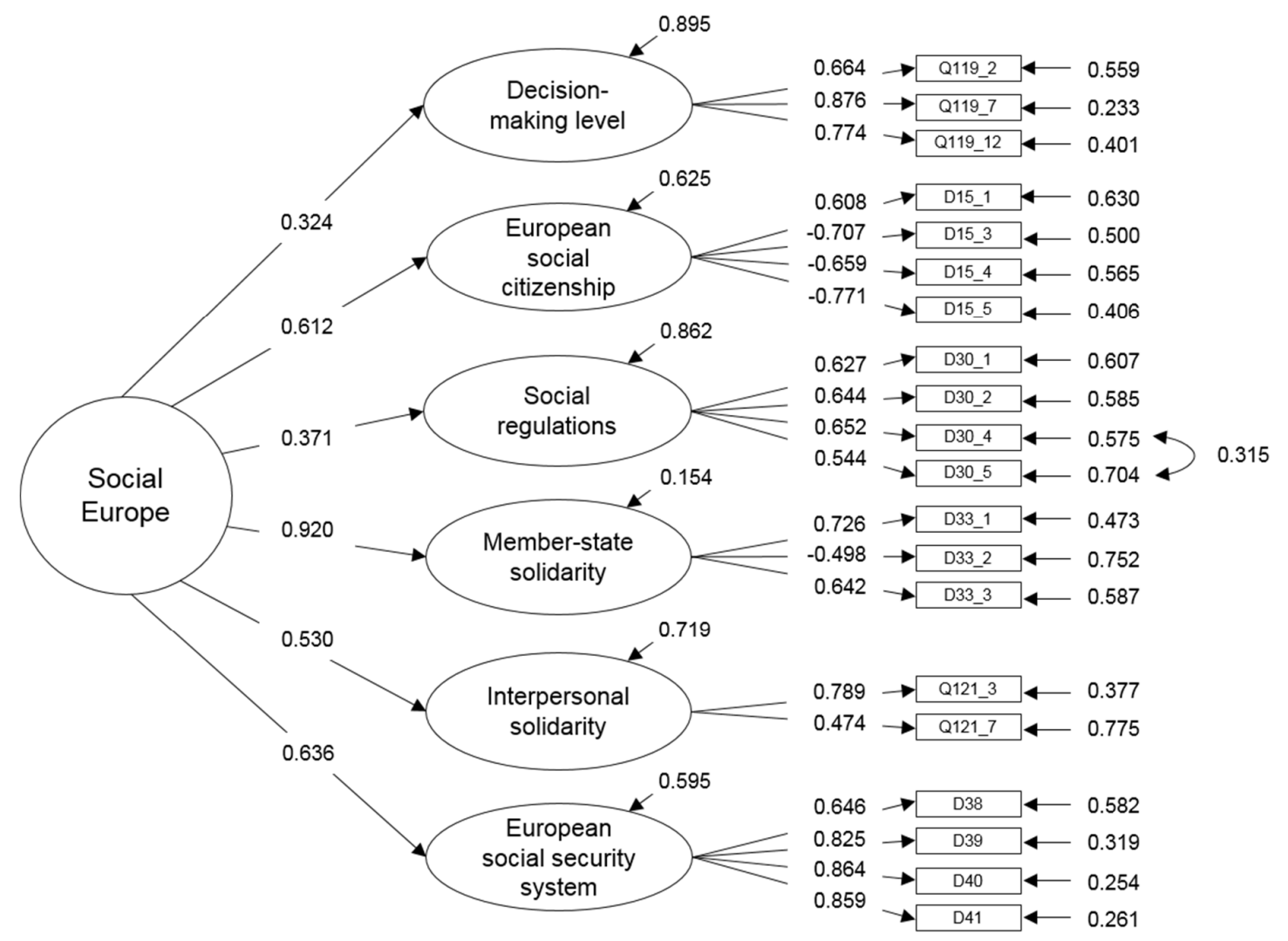

Source: BNES 2014.

Note: model fit indices of the CFA model: $X^{2}=511.951, d f=163, R M S E A=0.039, \quad S R M R=0.045$, $C F I=0.962, T L I=0.956$. All parameters are significant at the $p<0.001$ level.

In this measurement model (see Figure 1), all loadings of the items on the first-order factors have an absolute value larger than 0.40 , and mostly above 0.60 . This indicates that the items are sufficiently valid and are reliable indicators of the concepts they are intended to measure. The extent to which the specific dimensions overlap with the general concept of Social Europe can be derived from the second-order factor loadings. These loadings vary considerably in strength. The highest is observed for member-state solidarity: the loading of 0.920 implies that approximately 85 per cent of the variance in opinions on solidarity with other member states can be explained by the Social Europe second-order factor. Or from a different perspective, 
citizens' general attitudes towards Social Europe largely coincide with their opinions on whether the richest member states of the EU should support the less-affluent ones. In citizens' eyes, member-state solidarity seems to be the primary aspect of Social Europe. This is not completely unexpected, as the EU's various structural funds, which redistribute money from the more-affluent to the less-affluent member states, are the kernel of existing Social Europe. Although not measured directly, we assume that the impact of the European debt crisis and the rescue funds for Eurozone countries are important in this respect. The extensive debate about the bailouts for over-indebted member states might explain why citizens' general attitudes towards Social Europe rely so closely on their opinion about member-state solidarity.

Three dimensions show somewhat weaker but still considerable second-order factor loadings: 0.612 for European social citizenship, 0.530 for the principle of interpersonal solidarity, and 0.636 for the implementation of interpersonal solidarity through a European social security system. These dimensions share between 28 and 41 per cent of their variance with the general Social Europe factor, implying they are to a certain extent determined by it, however they do not overlap completely. Popular support for Social Europe therefore partly hinges on the views that all EU citizens should be given the same access to social rights, that more solidarity should exist between European citizens regardless of their country of residence, and that a common European welfare system should be developed.

The lowest second-order factor loading is found for the preferred decision-making level for social policy (0.324). This finding delegitimizes the common academic practice of using preferred decision-making level as a proxy for attitudes towards Social Europe. Furthermore, support for social regulations implemented by the EU is also weakly explained by the Social Europe construct $(0.371)$. Citizens responding favourably to these items might express their approval for these measures rather than support for the harmonizing role of the EU with regard to these social regulations. So neither the preferred decision-making level for social policy nor opinions on the harmonization of (implemented) social regulations in the EU substantially 
shape citizens' attitudes towards Social Europe. Whereas the first might be too abstract to measure support for Social Europe, the latter might be related to support for particular social policy measures.

\subsection{Preferred decision-making level: A valid measurement of attitudes towards Social Europe?}

Previous studies on support for European-level social policy have predominantly used the preferred decision-making level as a crucial indicator (Beaudonnet 2013; Mau 2005). However, our findings indicate that this dimension is only very weakly related to the secondorder factor. Consequently, it seems unjustified to consider the preferred decision-making level as a component of citizens' general attitude towards Social Europe. In order to shed light on this essential issue, we add to the factor model six additional items measuring attitudes towards the preferred level for decision making regarding two other policy areas. Concretely, we specify a model with two second-order factors (see Figure 2): (1) decision-making level, which contains the items concerning the preferred decision-making level for social policy (three items), for economic policy (three items) and for security and foreign policy (three items); and (2) Social Europe, measured by means of the remaining dimensions, thereby excluding the preferred decision-making level for social policy. This model tests the hypothesis that the preferred decision-making level for the area of social policy does not measure attitudes towards Social Europe, but instead indicates a preference for supranational policymaking in general. The model has an appropriate model fit (RMSEA $=0.039$; SRMR $=0.049$; $\mathrm{CFI}=0.948 ; \mathrm{TLI}=0.942)$ and presents interesting insights. First, the correlation between the two second-order factors (Social Europe and decision-making level) is moderately strong (0.379). Citizens in favour of supranational policy hold more positive views about Social Europe and vice versa. Nevertheless, Social Europe and the preferred decision-making level are clearly distinct concepts. The first-order factor loadings of the respective items for 
economic policy, security and foreign policy, and social policy show an expected pattern with most loadings higher than 0.60 . As expected, the second-order factor loadings on the Social Europe concept are similar to those in the previous model. The second-order factor loadings on the decision-making level construct equal 0.873 for social policy, 0.996 for economic policy and 0.507 for security and foreign policy. People's preferences regarding the level for decision making therefore correspond almost perfectly with their views on EU involvement in economic policies, but also with regard to social policy. The second-order factor loading for the decisionmaking level for social policy on the general decision-making construct is substantially stronger than the loading we observe on the Social Europe construct (0.324, see Figure 1). In this sense, the item on the preferred decision-making level for social policy seems to measure support for supranational policy-making rather than attitudes towards Social Europe. In other words, the policy-making dimension clearly trumps the social dimension. This finding is highly relevant for the assessment of previous research on Social Europe, which is unfortunately largely based on this specific indicator (Beaudonnet 2013; Berg 2007; Mau 2005). 
Figure 2: Second-order CFA model for decision-making level and Social Europe with standardized factor loadings (Model 5; $\mathrm{N}=1403$ ).

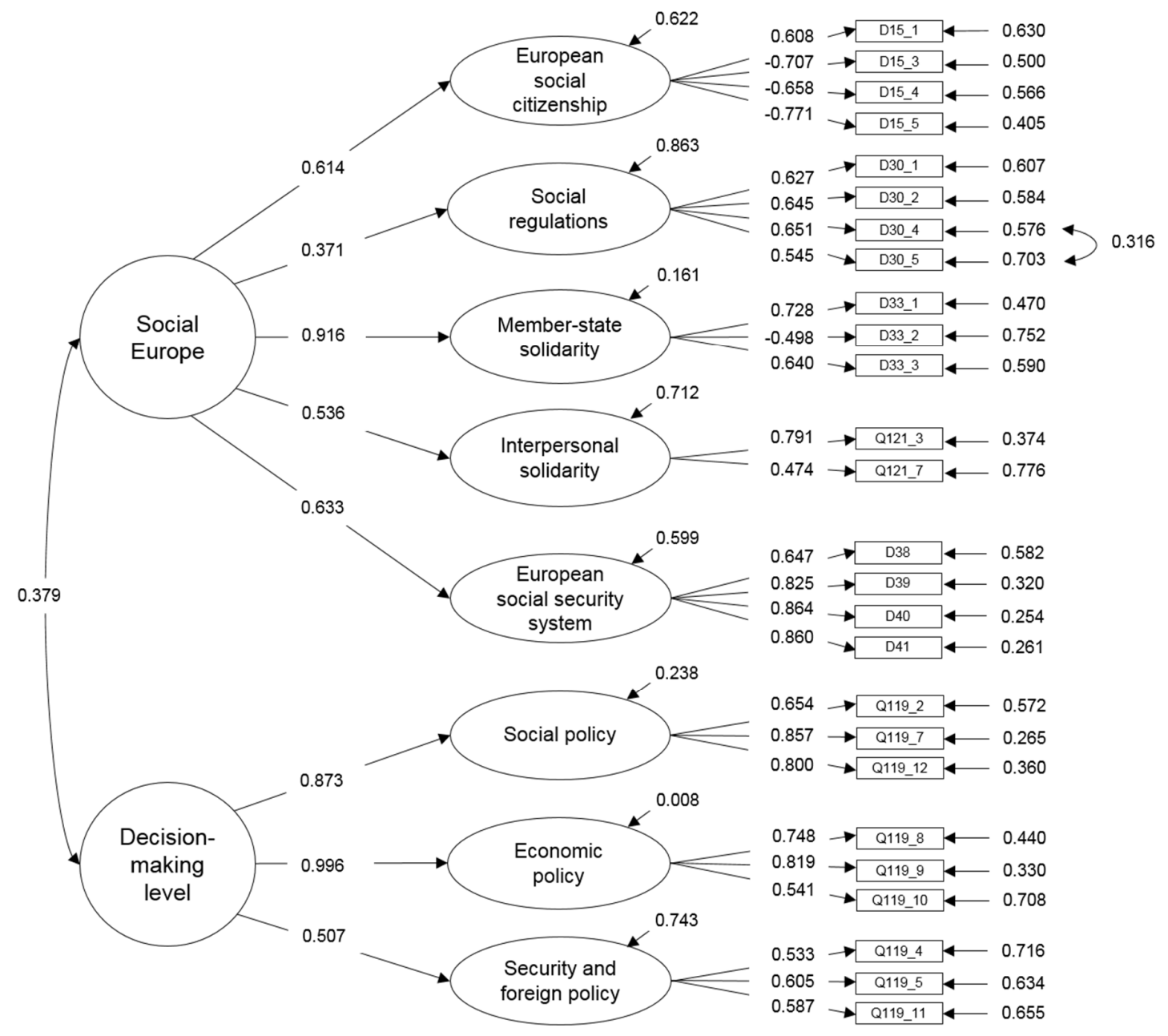

Source: BNES 2014.

Note: model fit indices of the CFA model: $X^{2}=910.535, d f=289, R M S E A=0.039, S R M R=0.049$, $C F I=0.948, T L I=0.942$. All parameters are significant at the $p<0.001$ level.

\subsection{Measurement equivalence among high-educated and low-educated people}

In order to draw valid conclusions, the meaning and interpretation of our measurement should be equivalent for all subgroups in the population. Because European-level social policy in its different aspects is a highly complex and intricate topic, it is possible that these survey measurements are too complex for lower-educated citizens. In their study on perceptions of 
Europe, Gaxie, Hubé and Rowell (2011) argue that survey questions on complex European issues are suitable instruments only for respondents with what is termed synoptic involvement, that is, those who know the technical and political particularities of European debates and who can discuss European issues with ease. To investigate whether our measurement of attitudes towards Social Europe may be biased depending on synoptic involvement, we investigate whether it is equivalent across higher and lower-educated respondents. In order to test this issue, we assume that education level is indicative of respondents' ability to understand European issues and respondents' familiarity with or interest in these issues (European Commission 2010). Our second-order measurement equivalence test (Byrne and Stewart 2006; Chen, Sousa, and West 2005) allows us to investigate whether citizens with different levels of education hold different understandings of the same questions, and whether the pattern and means of the various dimensions are comparable across both groups. Concretely, we perform a multigroup confirmatory factor analysis (MGCFA) of the second-order factor model Social Europe (including the first-order factors shown in Figure 2), comparing respondents who completed upper-secondary education or lower $(\mathrm{N}=835)$ with those who hold a tertiary educational degree $(\mathrm{N}=567)$.

Table 3 compares the fit indices of a series of models with different restrictions imposed. We start with a configurally-equivalent model (i.e. equal factor structures but no cross-group restrictions on loadings or intercepts). The configural model has a good fit (RMSEA=0.04; SRMR=0.046; $\mathrm{CFI}=0.966 ; \mathrm{TLI}=0.959$ ), implying that the number of factors and the pattern of factor loadings are similar among the low and the high educated, thus indicating that the same dimensional structure is found across both groups. However, this finding does not necessarily imply that meaningful comparisons of the latent factor Social Europe can be made between the two groups, as this would require scalar equivalence (i.e. equal factor loadings and intercepts). Therefore, in the next step we constrain the first-order and second-order factor loadings and intercepts (Model 2 in Table 3). Although this model shows a good fit $\left(X^{2}=670.628 ; R M S E A=0.048 ; S R M R=0.067 ; C F I=0.945 ; T L I=0.942\right)$, indicators of local misfit 
(modification indices and expected parameter changes) suggest releasing constraints on five parameters. These modifications improve model fit considerably (Model 3: $\Delta \chi^{2}=127.679$; $\triangle \mathrm{RMSEA}=0.008 ; \Delta \mathrm{SRMR}=0.015 ; \Delta \mathrm{CFI}=0.017 ; \Delta \mathrm{TLI}=0.017)$. Table 4 shows the factor loadings and intercepts for this final MGCFA model, which implies partial scalar equivalence of the first and second-order constructs. Below, we briefly discuss the deviations from full scalar equivalence.

First, the factor loadings for the item regarding whether or not there is too much tax money flowing from the prosperous EU countries to the poorer ones (d33_2) is considerably weaker for the lower educated $(-0.462)$ than for the higher educated $(-0.860)$. For the higher educated, the response to item d33_2 is more consistent with the other indicators of the dimension member-state solidarity than for the lower educated. A possible explanation is that the lower educated are less aware of the fact that this item has a reverse meaning in comparison with the other two items measuring member-state solidarity. Second, the intercept of the item regarding minimum paid leave (d30_4) is greater among the lower educated than among the higher educated (4.083 versus 3.940). In other words, if we compare lower and highereducated people who have the same level of support for social regulations, the former take a more favourable stance towards minimum paid leave. Third, the second-order factor loading for member-state solidarity is considerably stronger for the lower educated. In fact, for the lower educated, member-state solidarity overlaps completely with the second-order factor Social Europe. ${ }^{7}$ Lastly, two second-order intercepts are allowed to differ somewhat between the low and the high educated. Controlling for the second-order factor, the higher educated indicate slightly less approval for the principle of interpersonal solidarity, whereas they report somewhat greater levels of support for a European social citizenship. The MGCFA results confirm partial scalar equivalence, giving sufficient grounds for comparing the results of the lower and the higher educated in a reliable and valid way. The hypothesis that our

\footnotetext{
7 The (standardized) factor loading of member-state solidarity had to be constrained to 1 among the low educated, because the loading exceeded the value of 1 for this group.
} 
measurement instruments cannot be used for the lower educated is rejected. However, although the structure of attitudes towards Social Europe is similar for the low and the high educated, our analysis reveals significant differences in the level of support for Social Europe between the two groups: among the higher educated, overall levels of support for Social Europe are strongest $(0.090$ for the higher educated versus 0 for the lower educated, see Table 4).

Table 3: Fit statistics of MGCFA models for the second-order factor model Social Europe among the low and the high educated $(\mathrm{N}=1402)$

\begin{tabular}{|l|l|l|l|l|l|l|l|}
\hline Model & Description & $\mathrm{X}^{2}$ & $\mathrm{df}$ & $\mathrm{RMSEA}$ & $\mathrm{SRMR}$ & $\mathrm{CFI}$ & $\mathrm{TLI}$ \\
\hline 1 & Configural invariance & 481.267 & 227 & 0.040 & 0.046 & 0.966 & 0.959 \\
\hline 2 & $\begin{array}{l}\text { First-order and second-order factor loadings } \\
\text { and intercepts invariant }\end{array}$ & 670.628 & 258 & 0.048 & 0.067 & 0.945 & 0.942 \\
\hline 3 & $\begin{array}{l}\text { First-order and second-order factor loadings } \\
\text { and intercepts invariant with modifications }\end{array}$ & 542.949 & 254 & 0.040 & 0.052 & 0.962 & 0.959 \\
\hline
\end{tabular}


Table 4: Second-order scalar equivalence model among the low and the high educated - unstandardized and standardized (in parentheses) parameter estimates (modifications in bold, $\mathrm{N}=1402$ ). All parameters are significant at the $\mathrm{p}<0.001$ level.

\begin{tabular}{|c|c|c|c|c|c|c|c|c|c|c|c|c|}
\hline \multirow{3}{*}{$\begin{array}{c}\text { First-order } \\
\text { Member-state solidarity }\end{array}$} & \multicolumn{6}{|c|}{ Low educated } & \multicolumn{6}{|c|}{ High educated } \\
\hline & \multicolumn{5}{|c|}{ Factor loading } & \multirow[t]{2}{*}{ Intercept } & \multicolumn{5}{|c|}{ Factor loading } & \multirow[t]{2}{*}{ Intercept } \\
\hline & & & & & & & & & & & & \\
\hline D33_1 & $1(0.69)$ & & & & & $2.82(3.02)$ & $1(0.74)$ & & & & & $2.82(3.09)$ \\
\hline D33_2 & $-0.46(-0.33)$ & & & & & $3.34(3.74)$ & $-0.86(-0.69)$ & & & & & $3.34(3.99)$ \\
\hline D33_3 & $0.84(0.62)$ & & & & & $3.38(3.84)$ & $0.84(0.71)$ & & & & & $3.38(4.27)$ \\
\hline \multicolumn{13}{|l|}{ Interpersonal solidarity } \\
\hline Q121_3 & & $1(0.67)$ & & & & $3.54(3.88)$ & & $1(0.82)$ & & & & $3.54(3.97)$ \\
\hline Q121_7 & & $0.72(0.47)$ & & & & $3.40(3.64)$ & & $0.72(0.57)$ & & & & $3.40(3.69)$ \\
\hline \multicolumn{13}{|l|}{ European social citizenship } \\
\hline D15_1 & & & $1(0.55)$ & & & $2.71(2.52)$ & & & $1(0.63)$ & & & $2.71(2.67)$ \\
\hline D15_3 & & & $-1.17(-0.66)$ & & & $3.45(3.29)$ & & & $-1.17(-0.73)$ & & & $3.45(3.37)$ \\
\hline D15_4 & & & $-0.95(-0.63)$ & & & $4.08(4.55)$ & & & $-0.95(-0.64)$ & & & $4.08(4.30)$ \\
\hline D15_5 & & & $-1.30(-0.76)$ & & & $3.99(3.95)$ & & & $-1.30(-0.76)$ & & & $3.99(3.65)$ \\
\hline \multicolumn{13}{|l|}{ Social regulations } \\
\hline D30_1 & & & & $1(0.59)$ & & $4.17(6.17)$ & & & & $1(0.67)$ & & $4.17(7.14)$ \\
\hline D30_2 & & & & $1.51(0.63)$ & & $3.67(3.83)$ & & & & $1.51(0.65)$ & & $3.67(4.02)$ \\
\hline D30_4* & & & & $1.24(0.66)$ & & $4.08(5.40)$ & & & & $1.24(0.68)$ & & $3.94(5.55)$ \\
\hline D30_5* & & & & $1.27(0.53)$ & & $3.84(4.00)$ & & & & $1.27(0.58)$ & & $3.84(4.48)$ \\
\hline \multicolumn{13}{|l|}{ European social security system } \\
\hline D38 & & & & & $1(0.61)$ & $2.33(2.72)$ & & & & & $1(0.69)$ & $2.33(2.88)$ \\
\hline D39 & & & & & $1.28(0.79)$ & $2.49(2.94)$ & & & & & $1.28(0.87)$ & $2.49(3.03)$ \\
\hline D40 & & & & & $1.29(0.83)$ & $2.51(3.09)$ & & & & & $1.29(0.91)$ & $2.51(3.18)$ \\
\hline D41 & & & & & $1.28(0.83)$ & $2.42(3.03)$ & & & & & $1.28(0.89)$ & $2.42(3.00)$ \\
\hline Second-order & \multicolumn{5}{|c|}{ Factor loading } & Intercept & \multicolumn{5}{|c|}{ Factor loading } & Intercept \\
\hline Member-state solidarity & $4.87(1)$ & & & & & $0(0)$ & $3.30(0.91)$ & & & & & $0(0)$ \\
\hline Interpersonal solidarity & & $2.38(0.52)$ & & & & $0(0)$ & & $2.38(0.60)$ & & & & $-0.28(-0.38)$ \\
\hline European social citizenship & & & $2.32(0.52)$ & & & $0(0)$ & & & $2.32(0.67)$ & & & $0.21(0.33)$ \\
\hline Social regulations & & & & $1(0.33)$ & & $0(0)$ & & & & $1(0.47)$ & & $0(0)$ \\
\hline European social security system & & & & & $2.01(0.51)$ & $0(0)$ & & & & & $2.01(0.66)$ & $0(0)$ \\
\hline Mean score Social Europe & \multicolumn{6}{|c|}{0} & \multicolumn{6}{|c|}{0.09} \\
\hline Fit indices & $x^{2}=542.949$ & 254 RMSE & $=0.040$ SRMR & $0.052 \mathrm{CFI}=$ & $22 \mathrm{TLI}=0.95$ & & & & & & & \\
\hline
\end{tabular}

* Covariance between D30_4 and D30_5 allowed. 


\section{Discussion and conclusion}

The contributions of this study to the conceptualization and measurement of citizens' attitudes regarding Social Europe are threefold. First, we elaborated the notion of 'Social Europe' conceptually by defining it as a multidimensional concept that refers to various instruments and principles of solidarity at European level. Second, our empirical analysis confirms that citizens indeed have attitudes to five different, but interrelated, aspects of Social Europe, i.e. attitudes concerning European social citizenship, harmonization through social regulations, member-state solidarity, interpersonal solidarity and a European social security system. In addition, our research indicates that member-state solidarity is clearly the primary aspect of Social Europe in public opinion, whereas the feature that has received most scholarly attention in empirical research to date - the preferred decision-making level for social policy - cannot be considered as a key component of attitudes towards Social Europe. Third, our proposed multidimensional measurement of Social Europe proves to be a valid instrument for both high and low-educated people, rejecting the proposition that Social Europe is a concept that is too complex to be measured among the lower-educated population.

These findings have several repercussions for the interpretation of previous studies as well as for future research. Our analyses reveal that the most-often investigated item in previous research - the preferred decision-making level for social policy - is measuring support for European integration in general, but is not constitutive to citizens' opinions towards the social aspect of European integration. Accordingly, it is misleading to use this indicator to draw conclusions about citizens' attitudes towards Social Europe (Mau 2005) or a European social policy (Beaudonnet 2013). Based on our findings, we recommend including at least three of the following constitutive components to measure the overall attitude towards Social Europe: member-state solidarity, European social citizenship and the European social security system. 
The validation of our measurement instrument is time and space dependent. Events such as the Greek crisis, the refugee crisis and the Brexit referendum - just to mention a few - point to the fact that cross-nationally different meanings of Social Europe probably exist. In addition, the meaning of Social Europe is likely to be related to the social protection level of the national welfare system. For instance, harmonization of social policies might be an important component of Social Europe in the minds of citizens living in less-developed welfare states, whereas this may be less relevant for citizens in well-developed welfare states, in which EU social regulations improve existing social protection to a lesser degree. Furthermore, the finding that member-state solidarity functions as a 'master template' must be treated with great care in a cross-national perspective, because this aspect of Social Europe possibly does not equally contribute to citizens' overall attitude towards Social Europe across member states. In net-contributing countries, member-state solidarity might be a sensitive topic that dominates the debate on Social Europe in general. In net-receiving countries, the relevance of Social Europe's separate components may be more balanced. In addition, the politicized debate about financial aid for debt-ridden member states in recent years may partly explain why citizens' attitudes towards member-state solidarity coincide so strongly with their overall attitudes regarding Social Europe - at least in the Belgian case. Nevertheless, further research needs to shed light on the cross-national and cross-temporal validity of our instrument.

In addition, future contributions could expand the scope of the attitudes that are included. The proposed measurement focuses on the content of Social Europe; on its policy principles and to a limited extent on its policy instruments. New measurements might focus additionally on Social Europe's policy instruments, as they are not fully captured in our approach. Furthermore, a measurement of Social Europe might also include citizens' attitudes towards the social policy priorities for the European Commission (Burgoon 2009), the performance of the European social policy (Beaudonnet and Di Mauro 2012) and its (un)intended consequences, in order to shed more light on the multi-layered nature of attitudes towards Social Europe. 
In the near future, studies concerning the measurement of attitudes towards Social Europe should certainly be complemented by research on the determinants of citizens' attitudes towards its various dimensions, because a new integration-demarcation conflict (Kriesi et al. 2008) between winners and losers of globalization might emerge. The opening of national welfare boundaries and restructuring at the European level are expected to be supported differently among different groups within national communities, as well as between EU member states, depending on whether people perceive Social Europe as a threat or an opportunity. Lastly, researchers should also investigate the extent to which attitudes towards Social Europe go beyond Euroscepticism as such, and whether Europeans' perceptions of the EU's impact on national welfare states elicit negative or positive attitudes towards further European (social) integration. 


\section{Appendix 1: Support for Social Europe among Belgians (percentages weighted by age, gender and education)}

\begin{tabular}{|c|c|c|c|c|c|c|}
\hline \multirow[t]{2}{*}{$\begin{array}{l}\text { Decision- } \\
\text { making level a }\end{array}$} & \multicolumn{6}{|c|}{$\begin{array}{l}\text { Can you tell me for each of the following policy domains whether decisions in those domains should, } \\
\text { according to you, be taken exclusively by the European Union, primarily by the European Union, primarily } \\
\text { at the national level or exclusively at the national level? }\end{array}$} \\
\hline & & $\begin{array}{l}\text { Exclusively } \\
\text { national } \\
\text { level }\end{array}$ & $\begin{array}{l}\text { Primarily } \\
\text { national } \\
\text { level }\end{array}$ & $\begin{array}{l}\text { Primarily } \\
\text { EU }\end{array}$ & $\begin{array}{l}\text { Exclusively } \\
\text { EU }\end{array}$ & \\
\hline Q119_2 & Health care & 35.69 & 42.83 & 15.47 & 6.01 & \\
\hline Q119_7 & Pensions & 43.29 & 42.44 & 10.14 & 4.13 & \\
\hline Q119_12 & Unemployment benefits & 40.68 & 44.60 & 9.90 & 4.82 & \\
\hline \multirow[t]{2}{*}{$\begin{array}{l}\text { European } \\
\text { social } \\
\text { citizenship }\end{array}$} & \multicolumn{6}{|c|}{$\begin{array}{l}\text { Now we would like to ask your opinion on whether EU citizens should have access to social security in } \\
\text { Belgium. By EU citizens we mean people who have come to Belgium from other EU member states and } \\
\text { live here. Social security provides citizens with an income in case of illness, unemployment and disability. } \\
\text { To what extent do you agree or disagree with the following statements? }\end{array}$} \\
\hline & & $\begin{array}{l}\text { Completely } \\
\text { disagree }\end{array}$ & Disagree & $\begin{array}{l}\text { Neither } \\
\text { agree nor } \\
\text { disagree }\end{array}$ & Agree & $\begin{array}{l}\text { Completely } \\
\text { agree }\end{array}$ \\
\hline D15_1 & $\begin{array}{l}\text { EU citizens should receive the same } \\
\text { social facilities as Belgians }\end{array}$ & 10.49 & 27.83 & 30.32 & 26.58 & 4.77 \\
\hline D15_3 & $\begin{array}{l}\text { In the allocation of social benefits } \\
\text { Belgians should have priority over EU } \\
\text { citizens }\end{array}$ & 4.10 & 22.41 & 25.15 & 36.31 & 12.03 \\
\hline D15_4 & $\begin{array}{l}\text { EU citizens should first have a job } \\
\text { before they gain access to social } \\
\text { services }\end{array}$ & 1.37 & 6.91 & 17.32 & 45.65 & 28.75 \\
\hline D15_5 & $\begin{array}{l}\text { Let's support the poor in our country } \\
\text { first, before we help the poor coming } \\
\text { from other EU countries }\end{array}$ & 2.54 & 10.27 & 22.23 & 33.39 & 31.58 \\
\hline \multirow[t]{2}{*}{$\begin{array}{l}\text { Social } \\
\text { regulations }\end{array}$} & \multicolumn{6}{|c|}{$\begin{array}{l}\text { Below are a number of measures that the European Union has taken in recent years. Can you indicate for } \\
\text { each of the following measures whether it is a (very) good or a (very) bad thing that the EU has taken } \\
\text { these measures? }\end{array}$} \\
\hline & & $\begin{array}{l}\text { A very bad } \\
\text { thing }\end{array}$ & $\begin{array}{l}\text { A bad } \\
\text { thing }\end{array}$ & $\begin{array}{l}\text { Neither } \\
\text { good nor } \\
\text { bad }\end{array}$ & $\begin{array}{l}\text { A good } \\
\text { thing }\end{array}$ & $\begin{array}{l}\text { A very } \\
\text { good thing }\end{array}$ \\
\hline D30_1 & $\begin{array}{l}\text { The EU imposes a number of } \\
\text { obligations on employers to protect the } \\
\text { health and safety of workers }\end{array}$ & 0.22 & 1.33 & 9.42 & 58.71 & 30.32 \\
\hline D30_2 & $\begin{array}{l}\text { The EU prohibits a workweek of more } \\
\text { than } 48 \text { hours (including overtime) for } \\
\text { workers in the EU member states }\end{array}$ & 1.68 & 9.39 & 25.40 & 43.60 & 19.93 \\
\hline
\end{tabular}




\begin{tabular}{|c|c|c|c|c|c|c|}
\hline D30_4 & $\begin{array}{l}\text { The EU posits that workers in the EU } \\
\text { member states are entitled to paid } \\
\text { leave for a period of at least } 4 \text { weeks }\end{array}$ & 0.17 & 2.17 & 14.68 & 53.23 & 29.76 \\
\hline D30_5 & $\begin{array}{l}\text { The EU obliges all EU member states } \\
\text { to provide at least } 4 \text { months of paid } \\
\text { maternity leave to women who gave } \\
\text { birth }\end{array}$ & 1.28 & 5.92 & 20.67 & 42.87 & 29.26 \\
\hline $\begin{array}{l}\text { Member-state } \\
\text { solidarity }\end{array}$ & \multicolumn{6}{|c|}{$\begin{array}{l}\text { The following statements are about solidarity between member states of the European Union. To what } \\
\text { extent do you agree or disagree with the following statements? }\end{array}$} \\
\hline & & $\begin{array}{l}\text { Completely } \\
\text { disagree }\end{array}$ & Disagree & $\begin{array}{l}\text { Neither } \\
\text { agree nor } \\
\text { disagree }\end{array}$ & Agree & $\begin{array}{l}\text { Completely } \\
\text { agree }\end{array}$ \\
\hline D33_1 & $\begin{array}{l}\text { Rich EU countries such as Belgium } \\
\text { should always support other member } \\
\text { states that experience serious } \\
\text { economic difficulties }\end{array}$ & 6.34 & 28.30 & 37.62 & 25.59 & 2.15 \\
\hline D33_2 & $\begin{array}{l}\text { Too much tax money is going from the } \\
\text { prosperous EU countries to the poorer } \\
\text { EU countries }\end{array}$ & 2.49 & 13.90 & 43.73 & 33.11 & 6.76 \\
\hline D33_3 & $\begin{array}{l}\text { The solidarity between the richer and } \\
\text { poorer EU countries should not be } \\
\text { broken }\end{array}$ & 2.06 & 9.03 & 37.54 & 42.83 & 8.54 \\
\hline \multirow[t]{2}{*}{$\begin{array}{l}\text { Interpersonal } \\
\text { solidarity }\end{array}$} & \multicolumn{6}{|c|}{ To what extent do you agree or disagree with the following statements? } \\
\hline & & $\begin{array}{l}\text { Completely } \\
\text { disagree }\end{array}$ & Disagree & $\begin{array}{l}\text { Neither } \\
\text { agree nor } \\
\text { disagree }\end{array}$ & Agree & $\begin{array}{l}\text { Completely } \\
\text { agree }\end{array}$ \\
\hline Q121_3 & $\begin{array}{l}\text { A system of solidarity between all EU } \\
\text { citizens needs to be established }\end{array}$ & 2.50 & 13.44 & 23.00 & 54.43 & 7.63 \\
\hline Q121_7 & $\begin{array}{l}\text { The EU should take measures to } \\
\text { reduce income differences between all } \\
\text { EU citizens }\end{array}$ & 1.50 & 18.04 & 27.75 & 43.98 & 8.73 \\
\hline $\begin{array}{l}\text { European } \\
\text { social security } \\
\text { system }^{\text {a }}\end{array}$ & & $\begin{array}{l}\text { Completely } \\
\text { against }\end{array}$ & $\begin{array}{l}\text { Rather } \\
\text { against }\end{array}$ & $\begin{array}{c}\text { Rather } \\
\text { for }\end{array}$ & $\begin{array}{l}\text { Completely } \\
\text { for }\end{array}$ & \\
\hline D38 & General system $^{b}$ & 14.31 & 37.36 & 40.16 & 8.17 & \\
\hline D39 & Child benefit $^{\mathrm{b}}$ & 11.94 & 47.25 & 29.09 & 11.72 & \\
\hline D40 & Minimum income benefit ${ }^{b}$ & 10.94 & 49.06 & 30.00 & 10.00 & \\
\hline D41 & Unemployment benefit ${ }^{b}$ & 9.25 & 44.51 & 34.97 & 11.27 & \\
\hline
\end{tabular}

a Answer categories are reversed, ${ }^{b}$ Questioning is given in Appendix 2 


\section{Appendix 2: Survey questions on a European social security system}

\begin{tabular}{|c|c|}
\hline $\begin{array}{l}\text { D38 European } \\
\text { social security } \\
\text { system }\end{array}$ & $\begin{array}{l}\text { Currently, each member state of the European Union is responsible for its own system of } \\
\text { social security. This social security provides citizens a minimum protection in the event of } \\
\text { illness, old age, unemployment or disability. Some are saying we should stablish a common } \\
\text { system of social security within the European Union, to which all EU citizens pay } \\
\text { contributions. Are you for or against such a common system of social security at the EU level? }\end{array}$ \\
\hline $\begin{array}{l}\text { Introduction } \\
\text { D39-D41 }\end{array}$ & $\begin{array}{l}\text { In the social policy domain, the European Union can do many things. In the following four } \\
\text { questions we describe four different measures the European Union could possibly take. Are } \\
\text { you for or against these measures? }\end{array}$ \\
\hline $\begin{array}{l}\text { D39 } \\
\text { European child } \\
\text { benefit }\end{array}$ & $\begin{array}{l}\text { One possible measure is the introduction of a European child benefit. Through this measure } \\
\text { the EU guarantees a minimum benefit for children in the European Union that is adapted to } \\
\text { the cost of living in each country. To fund the European child benefit, each country would pay } \\
\text { according to its wealth. Additionally, member states could opt to further increase the child } \\
\text { benefit in their own country at their own expense. Are you for or against the introduction of } \\
\text { such a European minimum child benefit by the EU? }\end{array}$ \\
\hline $\begin{array}{l}\text { D40 } \\
\text { European } \\
\text { minimum } \\
\text { income benefit }\end{array}$ & $\begin{array}{l}\text { A second possible measure is the introduction of a European minimum income. Through this } \\
\text { measure the EU guarantees a minimum income benefit for all poor people in the European } \\
\text { Union that is adapted to the cost of living in each country. To fund the European minimum } \\
\text { income, each country would pay according to its wealth. Additionally, member states could } \\
\text { opt to further increase the minimum income in their own country at their own expense. Are } \\
\text { you for or against the introduction of such a European minimum income by the EU? }\end{array}$ \\
\hline $\begin{array}{l}\text { D41 } \\
\text { European } \\
\text { unemployment } \\
\text { benefit }\end{array}$ & $\begin{array}{l}\text { A third possible measure is the introduction of a European unemployment benefit. Through } \\
\text { this measure the EU guarantees a minimum unemployment benefit for all temporary } \\
\text { unemployed in the European Union that is adapted to the cost of living in each country. To } \\
\text { fund the European unemployment benefit, each country would pay according to its wealth. } \\
\text { Member states could opt to further increase the benefit in their country at their own expense. } \\
\text { Are you for or against the introduction of such a European unemployment benefit by the EU? }\end{array}$ \\
\hline
\end{tabular}




\section{References}

Abts, K., Swyngedouw, M., Meuleman, B., Baute, S., Galle, J., \& Gaasendam, C. (2015). Belgian National Election Study 2014. Codebook: Questions and frequency tables. Leuven: ISPO-KU Leuven \& CLEO - Université de Liège.

Alber, J. (2006). The European social model and the United States. European Union Politics, $7(3), 393-419$.

Allen, D. (2010). The structural funds and cohesion policy. In H. Wallace, M. A. Pollack, \& A. Young (Eds.), Policy-making in the European Union (6th ed., pp. 229-252). Oxford: Oxford University Press.

Allespach, M., \& Machnig, J. (2013). A change in course towards a social Europe. In A.M. Grozelier, B. Hacker, W. Kowalsky, J. Machnig, H. Meyer, \& B. Unger (Eds.), Roadmap to a social Europe. Social Europe report (pp. 92-94).

Anderson, J. (1995). Structural funds and the social dimension of EU policy: Springboard or stumbling block? In S. Leibfried \& P. Pierson (Eds.), European social policy: Between fragmentation and integration (pp. 123-158). Washington DC: The Brookings Institution.

Andor, L. (2016). Towards shared unemployment insurance in the euro area. IZA Journal of European Labor Studies, 5(10), 1-15.

Atkinson, A. B., \& Marlier, E. (2010). Income and living conditions in Europe. Luxembourg. Retrieved from http://ec.europa.eu/eurostat/documents/3217494/5722557/KS-31-10555-EN.PDF

Bartolini, S. (2005). Restructuring Europe: Centre formation, system building, and political structuring between the nation state and the European Union. Oxford: Oxford University Press.

Beaudonnet, L. (2012). You don't bite the hand that feeds you: The impact of redistribution on attitudes towards Europe. CSD Working Papers. Retrieved from http://escholarship.org/uc/item/3nh085bd

Beaudonnet, L. (2013). Preferences for European social policy in times of crisis. Politique européenne, 42(4), 96-123.

Beaudonnet, L. (2014). Take one for the team? A study of the individual bases for European solidarity in times of crisis. Presented at the $10^{\text {th }}$ European Community Studies Association - Canada biennial conference, Université de Montréal, Montreal, 8-10 May 2014.

Beaudonnet, L., \& Di Mauro, D. (2012). Support for Europe: Assessing the complexity of individual attitudes. In L. Beaudonnet and D. Di Mauro (Eds.), Beyond Euro-skepticism: Understanding attitudes towards the EU, European Integration Online Papers, special issue 2, vol. 16, article 9, http://eiop.or.at/eiop/texte/2012-009a.htm

Bechtel, M. M., Hainmueller, J., \& Margalit, Y. (2014). Preferences for international redistribution: The divide over the Eurozone bailouts. American Journal of Political Science, 58(4), 835-856. 
Berg, L. (2007). Multi-level Europeans. The influence of territorial attachments on political trust and welfare attitudes (Doctoral dissertation, Göteborg University, Göteborg, Sweden). Retrieved from https:/gupea.ub.gu.se/bitstream/2077/17144/7/ gupea_2077_17144_7.pdf

Boomgaarden, H. G., Schuck, A. R. T., Elenbaas, M., \& de Vreese, C. H. (2011). Mapping EU attitudes: Conceptual and empirical dimensions of Euroscepticism and EU support. European Union Politics, 12(2), 241-266.

Bruzelius, C., Chase, E., \& Seeleib-Kaiser, M. (2014). Semi-sovereign welfare states, social rights of EU migrant citizens and the need for strong state capacities. Oxford Institute of Social Policy. Retrieved from http://socialeurope.eu/wp-content/uploads/2014/12/RE3Seeleib.pdf

Byrne, B., \& Stewart, S. M. (2006). Teacher's corner: The MACS approach to testing for multigroup invariance of a second-order structure: A walk through the process. Structural Equation Modeling, 13(2), 287-321.

Büchs, M. (2007). New governance in European social policy: The open method of coordination (Vol. 15). Basingstoke: Palgrave Macmillan.

Burgoon, B. (2009). Social nation and social Europe: Support for national and supranational welfare compensation in Europe. European Union Politics, 10(4), 427-455.

Castles, F. G., Leibfried, S., Lewis, J., Obinger, H., \& Pierson, C. (2010). The Oxford handbook of the welfare state. Oxford: Oxford University Press.

Cautrès, B. (2012). Multidimensionality of EU attitudes in France: An issue for the understanding of the politicization of attitudes towards the EU. In: L. Beaudonnet and D. Di Mauro (Eds.), Beyond Euro-skepticism: Understanding attitudes towards the EU. European Integration Online Papers, special issue 2, vol. 16, article 7, http://eiop.or.at/eiop/texte/2012-007a.htm

Crum, B. (2011). What do we owe the Poles (or the Greeks)? Three emerging Duties of transnational social justice in the European Union. RECON Online Working Paper 2011/35. Retrieved from www.reconproject.eu/projectweb/portalproject/ RECONWorkingPapers.html

Davidov, E., Meuleman, B., Cieciuch, J., Schmidt, P., \& Billiet, J. (2014). Measurement equivalence in cross-national research. Annual Review of Sociology, 40(1), 55-75.

De Winter, L., \& Swyngedouw, M. (1999). The scope of EU government. In Schmitt, H., \& Thomassen, J., (Eds.), Political representation and legitimacy in the European Union (pp. 47-73). Oxford: Oxford University Press.

De la Porte, C., \& Pochet, P. (2012). Why and how (still) study the open method of coordination (OMC)? Journal of European Social Policy, 22(3), 336-349.

Dillman, D., Smyth, J., \& Christian, L. (2014). Internet, phone, mail, and mixed-mode surveys: The tailored design method. Hoboken: John Wiley \& Sons.

DiStefano, C. (2002). The impact of categorization with confirmatory factor analysis. Structural Equation Modeling, 9(3), 327-346. 
Dougan, M., \& Spaventa, E. (2005). Wish you weren't here... New models of social solidarity in the European Union. In M. Dougan \& E. Spaventa (Eds.), Social welfare and EU law (pp. 181-218). London: Hart Publishing.

Dullien, S. (2012). A European unemployment insurance as a stabilization device - Selected issues. Brussels. Paper prepared for brainstorming workshop on July 2, 2012 at the DG EMPL.

European Economic and Social Committee. (2013). Opinion of the European Economic and Social Committee on European minimum income and poverty indicators, SOC/482. Brussels, 10 December 2013. Retrieved from http://www.eesc.europa.eu/ ? $\mathrm{i}=$ portal.en.soc-opinions. 26780

Eichenberg, R. C., \& Dalton, R. J. (2007). Post-Maastricht blues: The transformation of citizen support for European integration, 1973-2004. Acta Politica, 42(2-3), 128-152.

European Commission. (2007). Standard Eurobarometer 65 / Spring 2006: Public opinion in the European Union. Brussels.

European Commission. (2010). Standard Eurobarometer 73 / Spring 2010: Public opinion in the European Union. Brussels.

European Commission. (2014). Standard Eurobarometer 81 / Spring 2014: Public opinion in the European Union. Brussels

European Commission. (2015). EU budget 2014: Financial report. Luxembourg. Retrieved from http://ec.europa.eu/budget/financialreport/2014/expenditure/allocation/ index_en.html

European Parliament (2015). The principle of subsidiarity. Retrieved from http://www.europarl.europa.eu/ftu/pdf/en/FTU_1.2.2.pdf

Faist, T. (2001). Social citizenship in the European Union: Nested membership. Journal of Common Market Studies, 39(1), 37-58.

Falkner, G. (2009a). European integration and the welfare state(s) in Europe. Working paper 3. Vienna: Institute for European Integration Research, Austrian Academy of Sciences.

Falkner, G. (2009b). The EU's social dimension. In M. Cini \& N. P.-S. Borragán (Eds.), European Union Politics (3rd ed., pp. 275-290). Oxford: Oxford University Press.

Falkner, G. (2010). European Union. In F. G. Castles, S. Leibfried, J. Lewis, H. Obinger, \& C. Pierson (Eds.), The Oxford handbook of the welfare state (pp. 292-305). Oxford: Oxford University Press.

Fattibene, D. (2015). Creating a union with a "human face": A European unemployment insurance. Retrieved from http://www.socialeurope.eu/2015/07/creating-union-humanface-european-unemployment-insurance/

Fernandes, S., \& Maslauskaite, K. (2013a). A social dimension for the EMU: Why and how? Policy Paper 98, Notre Europe - Jacques Delors Institute. Retrieved from http://www.notre-europe.eu/media/socialdimensionsforeumfernandesmaslauskaitenejdisept2013.pdf?pdf=ok 
Fernandes, S., \& Maslauskaite, K. (2013b). Deepening the EMU: How to maintain and develop the European social model? A study for the Federal Chancellery of Austria. Studies and reports, Notre Europe - Jacques Delors Institute.

Fernandes, S., \& Rubio, E. (2012). Solidarity within the Eurozone: How much, what for, for how long? Policy Paper 51, Notre Europe - Jacques Delors Institute. Retrieved from http://www.institutdelors.eu/media/solidarityemus.fernandese.rubionefeb2012.pdf?pdf=ok

Ferrera, M. (2005). The Boundaries of welfare: European integration and the new spatial politics of social protection. Oxford: Oxford University Press.

Ferrera, M. (2014). Social Europe and its components in the midst of the crisis: A conclusion. West European Politics, 37(4), 825-843.

Fichtner, F. (2014). Euro area-wide unemployment insurance: useless, desirable, or indispensable? In D. Natali (Ed.), Social developments in the European Union 2013 (pp. 115-130). Brussels: ETUI aisbl.

Føllesdal, A., Giorgi, L., \& Heuberger, R. (2007). Envisioning European solidarity between welfare ideologies and the European social agenda. Innovation, 20(1), 75-89.

Gaxie, D., Hubé, N., \& Rowell, J. (2011). Perceptions of Europe. A comparative sociology of European attitudes. Colchester: ECPR Press.

Gerhards, J., \& Lengfeld, H. (2013). European integration, equality rights and people's beliefs: Evidence from Germany. European Sociological Review, 29(1), 19-31.

Gerhards, J., \& Lengfeld, H. (2015). European citizenship and social integration in the European Union. Abingdon: Routledge.

Gerhards, J., Lengfeld, H., \& Häuberer, J. (2014). The EU crisis and citizens support for a European welfare state. Arbeitspapier Nr. 30, Berliner Studien zur Soziologie Europas. Retrieved from http://www.polsoz.fu-berlin.de/soziologie/arbeitsbereiche/ makrosoziologie/arbeitspapiere/pdf/BSSE-Nr_-30.pdf

Gerrits, A. M. W. (2015). Solidarity and the European Union: From the welfare state to the Euro crisis. In E. Hillebrand \& A. M. Kellner (Eds.), Shaping a different Europe: Contributions to a critical debate. Bonn: Dietz Verlag J.H.W. Nachf.

Geyer, R. (2000). Exploring European social policy. Cambridge: Polity Press.

Giubboni, S. (2014). European citizenship and social rights in times of crisis. German Law Journal, 15(5), 935-964.

Gold, M. (1993). The social dimension: Employment policy in the European Community. Basingstoke: Macmillan.

Grozelier, A.M., Hacker, B., Kowalsky, W., Machnig, J., Meyer, H., \& Unger, B. (2013). Roadmap to a social Europe. Social Europe report. 
Habermas, J. (2013). Democracy, solidarity and the European crisis. In A.M. Grozelier, B. Hacker, W. Kowalsky, J. Machnig, H. Meyer, \& B. Unger (Eds.), Roadmap to a social Europe. Social Europe report (pp. 4-13).

Heggestad, E. D., Rogelberg, S., Goh, A., \& Oswald, F. L. (2015). Considering the effects of nonresponse on correlations between surveyed variables. Journal of Personnel Psychology, 14(2), 91-103.

Hodson, D., \& Maher, I. (2001). The open method as a new mode of governance: The case of soft economic policy co-ordination. Journal of Common Market Studies, 39(4), 719746.

Jepsen, M., \& Pascual, A. S. (2005). The European social model: An exercise in deconstruction. Journal of European Social Policy, 15(3), 231-245.

Kleinman, M. (2002). A European welfare state? European Union social policy in context. Basingstoke: Palgrave.

Kriesi, H., Grande, E., Lachat, R., Dolezal, M., Bornschier, S., \& Frey, T. (2008). West European politics in the age of globalization. Cambridge: Cambridge University Press.

Leibfried, S. (2000). National welfare states, European integration and globalization: A perspective for the next century. Social Policy \& Administration, 34(1), 44-63.

Leibfried, S. (2015). Social policy: Left to the judges and the markets? In H. Wallace, W. Wallace, \& M. A. Pollack (Eds.), Policy-making in the European Union (7th ed., pp. 263292). Oxford: Oxford University Press.

Leibfried, S., \& Pierson, P. (1995). European social policy: Between fragmentation and integration. Washington DC: The Brookings Institution.

Lengfeld, H., Schmidt, S., \& Häuberer, J. (2015). Is there a European solidarity? Attitudes towards fiscal assistance for debt-ridden European Union member states. SSRN Electronic Journal. Retrieved from http://papers.ssrn.com/abstract=2597605

Levy, H., Matsaganis, M., \& Sutherland, H. (2013). Towards a European Union child basic income? Within and between country effects. International Journal of Microsimulation, 6(1), 63-85.

Magnusson, L., \& Stråth, B. (2004). A European social citizenship? Preconditions for future policies from a historical perspective. Brussels: P.I.E.-Peter Lang.

Majone, G. (1993). The European Community between social policy and social regulation. Journal of Common Market Studies, 31(2), 153-170.

Martinsen, D. S., \& Vollaard, H. (2014). Implementing social Europe in times of crises: Reestablished boundaries of welfare? West European Politics, 37(4), 677-692.

Mau, S. (2005). Democratic demand for a social Europe? Preferences of the European citizenry. International Journal of Social Welfare, 14(2), 76-85.

Mau, S., \& Verwiebe, R. (2010). European societies: Mapping structure and change. Bristol: Policy Press. 
Mewes, J., \& Mau, S. (2012). Unraveling working-class welfare chauvinism. In S. Svallfors (Ed.), Contested welfare states: Welfare attitudes in Europe and beyond (pp. 119-157). Stanford: Stanford University Press.

Muthén, B., \& Kaplan, D. (1985). A comparison of some methodologies for the factor analysis of non-normal Likert variables. British Journal of Mathematical and Statistical Psychology, 38(2), 171-189.

Nida-Rümelin, J., Hirschel, D., Meyer, H., Meyer, T., Möller, A., Scheer, N., ... Schwengel, H. (2013). We need a Europe that is truly social and democratic: The case for a fundamental reform of the European Union.

Pena-Casas, R., \& Denis, B. (2014). Towards a European minimum income? Discussions, issues and prospects. In D. Natali (Ed.), Social developments in the European Union 2013 (pp. 131-159). Brussels: ETUI aisbl.

Pierson, P., \& Leibfried, S. (1995). Multitiered Institutions and the Making of Social Policy. In S. Leibfried \& P. Pierson (Eds.), European social policy: Between fragmentation and integration (pp. 1-40). Washington DC: The Brookings Institution.

Pochet, P. (2005). The open method of coordination and the construction of social Europe: A historical perspective. In J. Zeitlin \& P. Pochet (Eds.), The open method of coordination in action: The European employment and social inclusion strategies (pp. 37-82). Brussels: P.I.E. Peter Lang

Porte, C. d. I., Pochet, P., \& Room, B. G. (2001). Social benchmarking, policy making and new governance in the EU. Journal of European Social Policy, 11(4), 291-307.

Raspotnik, A., Jacob, M., \& Ventura, L. (2012). Discussion paper: The issue of solidarity in the European Union. TEPSA Brief. Retrieved from http://www.tepsa.eu/tepsa-brief-theissue-of-solidarity-in-the-european-union/

Ray, L. (2004). Don't rock the boat: Expectations, fears, and opposition to EU-level policymaking. In G. Marks \& M. Steenbergen (Eds.), European integration and political conflict (pp. 51-61). Cambridge: Cambridge University Press.

Rhodes, M., \& Mény, Y. (1998). The future of European welfare: A new social contract? London: Palgrave Macmillan.

Roosma, F., Gelissen, J., \& van Oorschot, W. (2013). The multidimensionality of welfare state attitudes: A European cross-national study. Social Indicators Research, 113(1), 235-255.

Sangiovanni, A. (2013). Solidarity in the European Union. Oxford Journal of Legal Studies, 33(2), 1-29.

Schafer, J. L., \& Graham, J. W. (2002). Missing data: Our view of the state of the art. Psychological Methods, 7(2), 147-77.

Schall, C. E. (2012). Is the problem of European citizenship a problem of social citizenship? Social policy, federalism, and democracy in the EU and United States. Sociological Inquiry, 82(1), 123-144. 
Scharpf, F. W. (2002). The European social model: Coping with the challenges of diversity. Journal of Common Market Studies, 40(4), 645-670.

Seeleib-Kaiser, M. (2013). What is the social dimension of the EU? In A.M. Grozelier, B. Hacker, W. Kowalsky, J. Machnig, H. Meyer, \& B. Unger (Eds.), Roadmap to a social Europe (pp. 25-28). Social Europe report.

Threlfall, M. (2003). European social integration: Harmonization, convergence and single social areas. Journal of European Social Policy, 13(2), 121-139.

Threlfall, M. (2007). The social dimension of the European Union: Innovative methods for advancing integration. Global Social Policy, 7(3), 271-293.

Trubek, D. M., \& Trubek, L. G. (2005). Hard and soft law in the construction of social Europe: the role of the open method of co-ordination. European Law Journal, 11(3), 343-364.

van der Waal, J., Achterberg, P., Houtman, D., de Koster, W., \& Manevska, K. (2010). "Some are more equal than others": Economic egalitarianism and welfare chauvinism in the Netherlands. Journal of European Social Policy, 20(4), 350-363.

West, S. G., Finch, J. F., \& Curran, P. J. (1995). Structural equation models with nonnormal variables: Problems and remedies. In R. Hoyle (Ed.), Structural equation modeling: Concepts, issues, and applications (pp. 55-75). Thousang Oaks: Sage.

van Oorschot, W., \& Meuleman, B. (2012). Welfarism and the multidimensionality of welfare state legitimacy: Evidence from the Netherlands, 2006. International Journal of Social Welfare, 21(1), 79-93.

Vandenbroucke. (2013). A European social union: Why we need it, what it means. Rivista Italiana Di Politiche Pubbliche, 2(13), 221-247.

Vandenbroucke, F. (2014). The case for a European social union, European policy brief, 23.

Von Maydell, B., Borchardt, K., Henke, K.D., Leitner, R., Muffels, R., Quante, M., ... Zukowski, M. (2006). Enabling social Europe. Springer. 